\title{
READINESS TO CHANGE IN JEMURSARI ISLAMIC HOSPITAL IN CHANGE TO BE A EDUCATIONAL HOSPITAL
}

\author{
Rina Dwi Novita ${ }^{1}$, Nyoman Anita Damayanti ${ }^{1}$ \\ ${ }^{1}$ Department of Administration and Health Policy \\ Faculty of Public Health, Airlangga University, Surabaya, Indonesia \\ Correspondence Address: Rina Dwi Novita \\ Email : rinadnov@gmail.com
}

\begin{abstract}
Surabaya Islamic Hospital Foundation is preparing Jemursari Islamic Hospital to become an educational hospital bacause University of Nahdlatul Ulama Surabaya as a medical institution is required to have at least one primary educational hospital. Jemursari Islamic Hospital has conducted self assessment related to the readiness to become educational hospital in 2017 and resulted in a total value of $88.34 \%$. This research aims to describe the readiness to change at the Islamic Hospital Jemursari in the change into an educational hospital. This research was conducted at Islamic Hospital of Jemursari in period of October 2017-July 2018. This research is descriptive research because it describes readiness to change at Jemursari Islamic Hospital in the change to become educational hospital without any statistical calculation. This research is a quantitative research using cross-sectional method. Sampling method with proportional random sampling technique to get sample of 88 people spread in all work units at Jemursari Islamic Hospital. Data collection using questionnaires readiness guide for readiness assessment consisting of five indicators namely communication, sponsorship, stakeholder, readiness, and training. The results showed that the indicator of communication at Jemusari Islamic Hospital has the lowest average value (4.32) and has a slightly ready level. The stakeholder indicator has the highest average score (5.06) and has a ready level. In addition, indicators of sponsorship, readiness, and training have a ready level. In conclusion, based on these five indicators, most respondents $(87,23 \%)$ at Jemursari Islamic Hospital are ready to change from non-educational hospital to educational hospital. The advice given is to improve communication related to the change into an educational hospital, so that all indicators become ready.
\end{abstract}

Keywords: hospital, educational hospital, readiness to change

\begin{abstract}
ABSTRAK
Yayasan Rumah Sakit Islam Surabaya sedang mempersiapkan Rumah Sakit Islam Jemursari untuk menjadi rumah sakit pendidikan dikarenakan Universitas Nahdlatul Ulama Surabaya sebagai institusi pendidikan kedokteran diharuskan mempunyai minimal satu Rumah Sakit Pendidikan Utama. Rumah Sakit Islam Jemursari telah melakukan self assessment terkait kesiapan menjadi Rumah Sakit Pendidikan pada tahun 2017 dan menghasilkan total nilai sebesar $88,34 \%$. Penelitian ini bertujuan untuk menggambarkan readiness to change di Rumah Sakit Islam Jemursari dalam perubahan menjadi rumah sakit pendidikan. Penelitian ini dilakukan di Rumah Sakit Islam Jemursari pada periode Oktober 2017-Juli 2018. Penelitian ini merupakan penelitian deskriptif dikarenakan menggambarkan readiness to change di Rumah Sakit Islam Jemursari dalam perubahan menjadi rumah sakit pendidikan tanpa adanya perhitungan statistik. Penelitian ini merupakan penelitian kuantitatif dengan menggunakan metode crossectional. Cara pengambilan sampel dengan teknik proportional random sampling sehingga didapatkan sampel berjumlah 88 orang yang tersebar di seluruh unit kerja di Rumah Sakit Islam Jemursari. Pengambilan data menggunakan kuesioner readiness guide for readiness assessment yang terdiri dari lima indikator yaitu communication, sponsorship, stakeholder, readiness, dan training. Hasil penelitian menunjukkan bahwa pada indikator communication di RS Islam Jemursari memiliki nilai rata-rata paling rendah $(4,32)$ dan memiliki tingkat agak siap. Indikator stakeholder memiliki nilai rata-rata paling tinggi $(5,06)$ dan memiliki tingkat siap. Selain itu, indikator sponsorship, readiness, dan training memiliki tingkat siap. Kesimpulannya, berdasarkan kelima indikator tersebut, sebagian besar responden (85,23\%) di Rumah Sakit Islam Jemursari menyatakan siap untuk berubah dari rumah sakit non pendidikan menjadi rumah sakit pendidikan. Saran yang diberikan adalah memperbaiki komunikasi terkait perubahan menjadi rumah sakit pendidikan, sehingga seluruh indikator menjadi siap.
\end{abstract}

Kata kunci : rumah sakit, rumah sakit pendidikan, readiness to change 


\section{INTRODUCTION}

Hospitals were established to meet the needs of the community for health, in addition a hospital can also run the function of education in the field of health. Some hospitals are used by educational institutions as a place of education to produce doctors, dentists, and other health workers.

The types of hospitals based on affiliate relations with educational institutions are differentiated into two, namely educational hospitals and noneducational hospitals. The education system of health in Indonesia requires hospitals as a place of educational practice, such as the University of Nahdlatul Ulama Surabaya (UNUSA) who cooperate with Jemursari Islamic Hospital as a health practice facilitator for Faculty of Medicine students UNUSA. This is in accordance with KMK No. 1069 on the guidelines and Classification of Education hospital which mentions that each medical education institution must have at least one major education RS.

The education hospital according to the (Departement of Health., 2009) is a hospital that can perform the function of medical field education. Jemursari Islamic Hospital needs to meet the requirements and standards of education hospitals by improving the services provided in order to be administered as an education hospital. PP number 93 year 2015 distinguishes Education hospital into three, among other major educational hospitals, affiliate education hospitals, and satellite education hospitals. In this case, Jemursari Islamic Hospital is working on the change to become primary education Hospital.

In preparation of change to become primary education hospital, the leader of the Organization with the Team of Education Coordination Committee of Jemursari Islamic Hospital formulated new policies to drive change to run smoothly. According to the KMK No. 1069 on the guidelines and classification of educational hospitals, this education hospital standard is prepared in reference to the medical education standards established by the World Federation of Medical Education (WFME) consisting of several parts, Among others, the standards of vision, mission, and hospital commitment in the field of education; Management and education administration standards; Human resource standards; Standards of educational supporting facilities; and the design and implementation standards of a quality clinical education program.

Based on the results of self assessment done by the Jemursari Islamic Hospital in the readiness to become primary education hospital in 2017, the total value achieved by the Jemursari Islamic Hospital is still at $88.34 \%$. Jemursari Islamic Hospital still meets 43 of the total 52 parameters to be met. This indicsates there are still 9 more parameters that must be met. The standard is still not met namely standard 1, standard 2, and standard 5.

On the standard 1 related vision, mission, commitment and requirements, the unfulfilled parameters are 4 basic specialist services and 7 specialised services in the hospital. There are several parameters that have not been met in standard 2, among others, related to education information system, report on periodic education progress every year, quarterly financial statements of six monthly and yearly, evaluation document of education implementation Once every six months, and feedback data on all faculty and participants, feedback analysis, and follow-up. Some of these things can be an indication that the perception of compliance against time is still low. All parts of RS related to education programs are actively involved in the process of implementing education and evaluation of Clinical education program periodically through feedback mechanism is still not met on the design standards and Implementation of a Quality clinical 
education program, which is the fifth standard.

Parameters that have not been met indicate an indication that it is still necessary to do analysis of Jemursari Islamic HOSPITAL to main education HOSPITAL. Thus, the problem raised in this research is the new Jemursari Islamic Hospital meets $88.34 \%$ of the standards of the hospitals education in the year 2017 .

This research aims to describe the readiness to change in Jemursari Islamic Hospital in a change to the primary education RS. According to (Weiner, B.J., 2009) readiness to changes is indicative of an indication of the beliefs, attitudes, and intentions of members of the Organization regarding the need for organizational change and capacity to achieve a successful change. By adopting the theory of the Information Technology Leadership Academy (2004) in the Readiness Guide for Readiness Assessment can be known cause of problems in the Islamic Hospital Jemursari. There are five elements in the variable readiness to change, such as communication, sponsorship, stakeholders, readiness, and training.

Good exchange of information can support and reduce barriers during organizational changes through a communication so that employees can participate in the change process and reduce the perception factor of uncertainty. Communication is a fundamental pillar of change. Communication can help members of the organization to illustrate how stakeholders expose change and make organizational members perform in accordance with organizational changes. Without quality communication, members of the organization will not have the awareness and understanding they need to commit to and implement organizational changes (Information Technology Leadership Academy., 2014).

The sponsorship factor is very influential in the readiness of organizational change, such as those done by Jemursari Islamic Hospital, namely the support of the executive leaders. When one organization changes, members of the organization need leaders to get referrals and support. Support from this leader can build a commitment to all members of the organization.

Stakeholders are one of the important supporting factors in the organizational change process. In some organizations such as hospitals also need to manage a network of stakeholders to support the management process, such as organization leaders, medical and non medical staff, and patients. The fourth element in readiness to change is readiness or individual readiness. Readiness is established from each employee to always support organizational readiness to change. The fifth element is training. The primary purpose of training at the time of change takes place is to understand the gaps in organizational member skills and provide an opportunity to learn the skills before changes are applied to the organization.

\section{METHODS}

Research conducted at Jemursari Islamic Hospital located on Jalan Jemursari No. 51 - 57 Surabaya with the period October 2017 - July 2018.

This research is a descriptive research because researchers only do observations about readiness to change in the Jemursari Islamic HOSPITAL in the change to primary education HOSPITAL without giving the treatment and intervention to the respondent. The research uses quantitative research design and crossectional research methods.

The population of this research includes all employees with 727 people and research samples of 88 people. The sample size in this study is determined according to the formula Slovin $(\alpha=10 \%)$ :

$$
n=\frac{N}{1+N a^{2}}
$$


Description:

$\mathrm{n}=$ Large Sample

$\mathrm{N}=$ Large population

$\alpha=$ significance level

Thus, the calculation of large samples for this study is as follows:

$$
\begin{gathered}
n=\frac{727}{1+727(0,1)^{2}} \\
n=\frac{727}{8,27} \\
n=87,90
\end{gathered}
$$

Based on the above calculations, it can be noted that for a population of 727 people and a value of confidence interval of $10 \%(\alpha=0.1)$ Then the number of samples is 87.90 which is then rounded up to 88 people. Researchers specify a confidence interval value or type 1 error of $10 \%(\mathrm{~A}=$ 0.1 ) because this research is included in social research that impacts have no direct effect on community security.

Once a large sample is obtained, the sample selection is performed each working unit using proportional random sampling technique with the formula:

Description:

$$
n_{i}=\frac{N_{i} \times n}{N}
$$

$\mathrm{NI}=$ large samples on each strata

$\mathrm{Ni}=$ Large population in each strata

$\mathrm{n}=$ Large Total samples

$\mathrm{N}=$ Large total population

Data collection using primary data using the instrument questionnaire that has been tested validity and reliability. The questionnaire was given using a Likert scale with 6 answer options. The results of the questionnaire data were scoring to determine the value of each respondent.

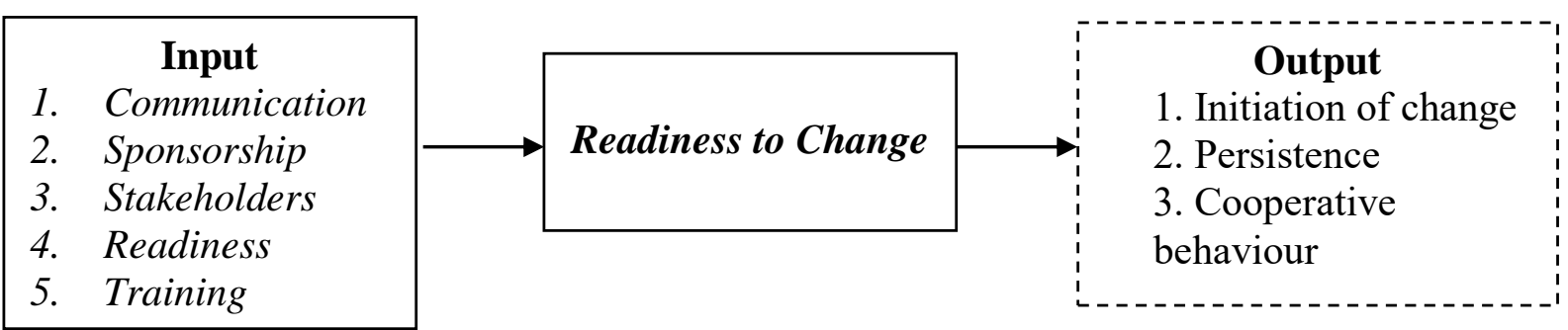

Figure 1. Conceptual framework

Description:

$$
\begin{array}{ll}
\hline & =\text { Researched } \\
&
\end{array}
$$

In Figure 1, based on Information Technology Leadership Academy (2004), to know the level of readiness to change, first have to measure communication, sponsorship, stakeholders, readiness, and training in Islamic HOSPITAL Jemursari. As a result of organizational readiness to change, the organizational readiness level to change will affect the willingness of organizational members to implement change. The willingness is reflected by initiation, persistence and cooperative behavior of members of the organization in the process of change (Weiner, 2009). This research has obtained a description of the passing of the Ethics commission of the FKM No: 78-KEPK.

\section{RESULT}

\section{Jemursari Islamic Hospital Overview}

Jemursari Islamic Hospital is the development of Surabaya A. Yani Islamic Hospital which started its operation on 25 May 2002. Jemursari Islamic Hospital received recognition as a type $\mathrm{B}$ hospital by 
the Ministry of Health at the end of 2011 with 200 beds in accordance with regulation of the Minister of Health No. 340 year 2010 on hospital classification. Readiness efforts to become an education hospital is also reflected in the vision of Jemursari Islamic $\mathrm{RS}$ is become a leading and trusted Islamic hospitals in service, education and research.

Based on the data retrieval conducted on the research sample of the 88 labor of Jemursari Islamic hospital. Here is an overview of the research respondent.

\section{Characteristics of respondents research}

Table 1. The distribution of officers at Jemursari Islamic HOSPITAL year 2018 based on gender, age, education level, and employment

\begin{tabular}{|c|c|c|c|}
\hline $\begin{array}{l}\text { Characteristics } \\
\text { of respondents }\end{array}$ & Gruop & $\mathbf{n}$ & $\%$ \\
\hline \multirow[t]{3}{*}{ Sex } & Male & 25 & 28,4 \\
\hline & Female & 63 & 71,6 \\
\hline & Total & 88 & 100 \\
\hline \multirow[t]{5}{*}{ Age } & $21-30$ & 54 & 61,36 \\
\hline & $31-40$ & 29 & 32,95 \\
\hline & $41-50$ & 4 & 4,55 \\
\hline & $51-60$ & 1 & 1,14 \\
\hline & Total & 88 & 100 \\
\hline \multirow{6}{*}{$\begin{array}{l}\text { Level } \\
\text { education }\end{array}$} & SMP & 1 & 1,14 \\
\hline & SMA & 7 & 7,95 \\
\hline & Diploma & 39 & 44,32 \\
\hline & Sarjana & 38 & 43,18 \\
\hline & $\begin{array}{l}\text { Pasca } \\
\text { Sarjana }\end{array}$ & 3 & 3,41 \\
\hline & Total & 88 & 100 \\
\hline \multirow{5}{*}{$\begin{array}{l}\text { Working } \\
\text { periodMasa } \\
\text { Kerja }\end{array}$} & $<2$ & 9 & 10,23 \\
\hline & $2-5$ & 41 & 46,59 \\
\hline & $>5-10$ & 20 & 22,73 \\
\hline & $>10$ & 18 & 20,45 \\
\hline & Total & 88 & 100 \\
\hline
\end{tabular}

The following are the results of the distribution of individual characteristics of respondents by gender in Table 1. Based on table 1 . Shows that the majority of femaletype respondents with a presentation of $71.6 \%$. The majority of respondents $(61.36 \%)$ Employees with a range of age 21 -30 years. Based on the characteristics of the education level shows that the majority of $43.18 \%$ workforce has diploma education level. While the majority of respondents $(46.59 \%)$ Have a working period of 2-5 years.

\section{Readiness to change at Jemursari Islamic Hospital}

Table 2. Level Readiness to Change Jemursari Islamic HOSPITAL year 2018

\begin{tabular}{lcc}
\hline $\begin{array}{c}\text { Readiness to } \\
\text { Change }\end{array}$ & $\begin{array}{c}\text { Amo } \\
\text { unt }\end{array}$ & $\begin{array}{c}\text { Persentase } \\
(\boldsymbol{\%})\end{array}$ \\
\hline Somewhat unprepared & 3 & 3,41 \\
Somewhat prepared & 10 & 11,36 \\
Ready & 59 & 67,05 \\
Very prepared & 16 & 18,18 \\
$\quad$ Total & $\mathbf{8 8}$ & $\mathbf{1 0 0 , 0 0}$ \\
\hline
\end{tabular}

Readiness to change in this research is measured through several indicators namely communication (communication), stakeholder (stakeholders), sponsorship (support), Readiness (readiness), and training (training) with instruments used is a questionnaire. Following is the result of data processing respondents related to readiness to change at Jemursari Islamic Hospital in Table 2.

The results showed that at Jemursari Islamic HOSPITAL there were as many as 75 people $(85.23 \%)$ Prepared and very prepared to change from non-educational hospitals to primary education hospital..

Readiness to Change indicator of Jemursari Islamic Hospital year 2018

Table 3. Readiness to Change Jemursari Islamic Hospital year 2018 in the change to be the primary education hospitals

\begin{tabular}{crc}
\hline $\begin{array}{c}\text { Readiness to } \\
\text { Change }\end{array}$ & Score & Description \\
\hline Communication & 4,32 & $\begin{array}{c}\text { Somewhat } \\
\text { unprepared }\end{array}$ \\
Stakeholders & 5,06 & Ready \\
Sponsorship & 4,87 & Ready \\
Readiness & 4,85 & Ready \\
Training & 4,86 & Ready \\
\hline
\end{tabular}


Based on the results of the data in Table 3 shows that four of the five indicators get a ready predicate which means the organization is ready to transform into a primary education hospital based on this research.

\section{Communication}

Table 4. Communication Indicator At Jemursari Islamic Hospital in 2018

\begin{tabular}{llc}
\hline No & \multicolumn{1}{c}{ Indicator } & Average \\
\hline 1 & $\begin{array}{l}\text { The hospital has communicated its vision, strategy and continuous change } \\
\text { plan delivered by management }\end{array}$ & 3,67 \\
2 & $\begin{array}{l}\text { Priorities regarding change have been established and delivered to } \\
\text { employees continuously }\end{array}$ & 4,08 \\
3 & $\begin{array}{l}\text { Hospitals use several methods of communication with interested parties to } \\
\text { keep information up to date }\end{array}$ & 4,64 \\
4 & $\begin{array}{l}\text { Clear and consistent message delivery of the changes } \\
5\end{array}$ & There are mechanisms to identify barriers to effective communication \\
\hline
\end{tabular}

Communication in this research is defined as the vision, mission, and strategy about the change to become a primary education hospital owned by the Jemursari Islamic Hospital continuously communicated to all stakeholders. It is revealed that the research results show communication at Jemursari Islamic Hospital in the change to home primary education hospital is at a level somewhat prepared. The continuity of communication regarding vision, strategy, and the plan of change into primary education hospital is an indicator with the lowest judgment. The highest rating communication indicator is delivering a message about change to primary education hospital done clearly, succinctly, and consistently, with an average value of 4.70 .

\section{Sponsorship}

Sponsorship in the research is defined as the Jemursari Islamic Hospital has an active sponsorship (support) at the executive level to implement change and push to achieve the desired outcome. The following is the result of the processing of employee perception data on the
The following is the frequency distribution of respondents assessment related to communication indicators at Jemursari Islamic Hospital year 2018 in Table 4. sponsorship indicators conducted by Jemursari Islamic Hospital in Table 5. Based on Table 5, you can know that the sponsorship at the Jemursari Islamic Hospital related to the change to the main education hospital has a level ready. Indicators that have the lowest judgment are related to the activation of the Executive leader's participation (director) in the change to primary education hospital with an average value of 4.78 . The indicators that have the highest judgment related to the authority over human resources, processes, and systems in the authorization and funding of change initiatives owned by the Executive leader (director) have the average value of most Height, which is 4.98.

\section{Stakeholders}

Stakeholders are stakeholders in the organization in the management cycle to support the change management process. The Stakeholders in this study are defined as the Jemursari Islamic Hospital has obtained and engaged the right person in the design and implementation of change into primary education hospital to ensure the implementation of the change. The 
following are the results of the processing of employee perception data on stakeholders indicators conducted by Jemursari Islamic Hospital on Table 6.

Tabel 5. Sponsorship indicators at Jemursari Islamic Hospital in 2018

\begin{tabular}{ll}
\hline \multicolumn{1}{c}{ Indicator } & Average \\
\hline Change initiatives in hospitals have clear executive leadership & 4,9 \\
$\begin{array}{l}\text { Executive leaders have the necessary authority over human resources, } \\
\text { processes, and systems in the authorization and funding of change }\end{array}$ & 4,98 \\
$\begin{array}{l}\text { initiatives } \\
\text { Executive leaders can build awareness of the need for change }\end{array}$ & 4,89 \\
$\begin{array}{l}\text { Executive leaders actively participate in the change process } \\
\begin{array}{l}\text { Executive leadership will solve the problem and make decisions related to } \\
\text { the change process }\end{array}\end{array}$ & 4,78 \\
\hline
\end{tabular}

Table 6. The Stakeholder indicator at Jemursari Islamic Hospital year 2018

\begin{tabular}{|c|c|}
\hline Indicator & Average \\
\hline $\begin{array}{l}\text { Executive Leadership } \\
\text { (Directors) are willing } \\
\text { and able to build a } \\
\text { coalition for change and } \\
\text { able to manage resistance } \\
\text { from all stakeholders }\end{array}$ & 5,16 \\
\hline $\begin{array}{l}\text { The changes are } \\
\text { effectively managed and } \\
\text { the success achieved is } \\
\text { expressed both internally } \\
\text { and publicly }\end{array}$ & 5,08 \\
\hline $\begin{array}{l}\text { Stakeholders receive } \\
\text { consistent and intact } \\
\text { messages from various } \\
\text { executive } \\
\text { regarding the process of } \\
\text { change }\end{array}$ & 4,94 \\
\hline $\begin{array}{l}\text { Initiative changes } \\
\text { accurately tailored to the } \\
\text { needs and interests of } \\
\text { each stakeholder group }\end{array}$ & 5,05 \\
\hline $\begin{array}{l}\text { Special strategies have } \\
\text { been developed to handle } \\
\text { resistance to changes } \\
\text { from various stakeholders }\end{array}$ & 5,10 \\
\hline
\end{tabular}

According to Table 6 It can be noted that stakeholder indicators have a level ready to change. The assessment of each indicator indicates that the consistency of the messages obtained by stakeholders from various executive tiers regarding the process of change by an average of 4.94 is the lowest indicator. The indicators that have the highest judgment are related to the ability of executive Leadership (director) to build a coalition for change and able to manage the resistance of all parties who have an interest with an average value of 5.16. This indicates that the executive leaders of Jemursari Islamic Hospital have formed a strong cooperation between the interested parties.

\section{Readiness}

Readiness in this study defined as the Jemursari Islamic Hospital can make members of the organization ready to adapt to changes and ensure they have the right information and tools. The following is the result of the processing of employee perception data on readiness indicators by Jemursari Islamic Hospital in Table 7. 
Table 7. Indicator Readiness at Jemursari Islamic Hospital in 2018

\begin{tabular}{ll}
\hline \multicolumn{1}{c}{ Indicator } & Average \\
\hline $\begin{array}{l}\text { The approach of change management has been communicated and applied } \\
\text { to the process of change into an educational hospital }\end{array}$ & 4,95 \\
$\begin{array}{l}\text { Changes to the management team members have been identified. } \\
\text { Management and staff have received training in organizational change }\end{array}$ & 4,78 \\
management programmes & \\
$\begin{array}{l}\text { The team responsible for the change monitors progress and is able to } \\
\text { solve problems related to the management process and has integrated the } \\
\text { plan of change }\end{array}$ & 4,79 \\
$\begin{array}{l}\text { Resources for change into an educational hospital have been identified } \\
\text { and acquired based on the plan of change }\end{array}$ & 4,90 \\
\hline
\end{tabular}

Based on table 7 can be noted that the readiness indicator has a level ready to change. The lowest scoring indicator is the change in the management team members with an average value of 4.78 . The highestscoring indicator is structured change management approach that has been communicated and applied to the change process into an educational hospital with an average value of 4.95 .

\section{Training}

Training in this research is defined as the Islamic Hospital Jemursari has conducted appropriate training to face changes to become a primary education Hospital for the resources owned by the organization. The following is the result of the processing of employee perception data on training indicators conducted by Jemursari Islamic Hospital in table 8.

Based on table 8 can be noted that the training indicator is at the level ready to change. Clarity of assessment of skills for change into primary education Hospital and the identification of gaps (gaps) in transition changes, with an average value of
4.74 is an indicator with the lowest judgment. Indicator with the highest average rating of 5.04 that is understanding the hospital understand about the competency of expertise and knowledge required by the employees to take the change to become primary education Hospital.

\section{DISCUSSION}

Jemursari Islamic Hospital is a hospital built in the year 1992 which is the development of the Islamic Hospital Surabaya A. Yani. The hospital started operations on 25 May 2002 and located at Jalan Jemursari 51-57 Suabaya with an area of $4.6 \mathrm{Ha}$. This hospital continues to develop until now in the year 2018 the Jemursari Islamic Hospital has had 269 bed fruit.

The manpower at Jemursari Islamic Hospital is more than a female gender with a percentage of $71.6 \%$ compared with male labor. This is due to the many female-sex workforce working in the health sector as opposed to male labor. 
Table 8. The Training indicator at Jemursari Islamic Hospital in 2018

\begin{tabular}{ll}
\hline \multicolumn{1}{c}{ Indicator } & Average \\
\hline $\begin{array}{l}\text { The hospital understands and strengthens the competence of the skills and } \\
\text { knowledge required by employees to respond to the change to become an } \\
\text { educational hospital }\end{array}$ & 5,04 \\
$\begin{array}{l}\text { The skills and knowledge needed for transition to change into an } \\
\text { educational hospital have been identified and standardized }\end{array}$ & 4,93 \\
$\begin{array}{l}\text { The top skills assessment has been made for the change to be an } \\
\text { educational hospital and the gap (GAP) on transition changes has been }\end{array}$ & 4,74 \\
$\begin{array}{l}\text { identified } \\
\text { The training was developed and proactively scheduled, based on the }\end{array}$ & 4,81 \\
$\begin{array}{l}\text { assessment of gaps and competency needs } \\
\text { The flexible method has been used for training. Examples: web-based } \\
\text { training; Guidance Training in the classroom and etc. }\end{array}$ & 4,77 \\
\hline
\end{tabular}

The manpower at Jemursari Islamic Hospital is the most that has an age of about 21-30 years with a percentage of $61.36 \%$. It shows that the manpower of both medical labor and non-medical manpower are still young. This is due to Jemursari Islamic Hospital, which includes the newly operated hospitals in the year 2002, so that the manpower that entered is also mostly a young workforce.

Most respondents have a diploma in education with a percentage of $44.32 \%$. However, it is not much different from the respondents who have a degree of undergraduate education with a percentage of $43.18 \%$. This shows that most of the manpower at the Jemursari Islamic Hospital have had educational experience up to college.

The most widely owned employment of respondents is the 2-5-year tenure of $46.59 \%$. This shows that the hospital received a lot of new personnel after the development in 2002. As it was known that the hospital had originally had only 82 beds in 2002, then the hospital underwent a growth every year to have as many as 269 beds in 2018. This is what makes hospitals need more manpower to run all the operations of the hospital, so that a lot of new workforce has a working period of about 2 to 5 years.

Readiness to change on this research is done by measuring on several indicators namely communication (communication), stakeholder (stakeholders), sponsorship (support), Readiness (readiness), and training (training) with instruments Used are questionnaires. The results showed that the respondents were ready and very prepared to change from non-educational hospitals to primary education hospital with a percentage of $85.23 \%$.

The first indicator that is used as a benchmark readiness to change at Jemursari Islamic Hospital is communication. The results showed that the communication indicator is still in a somewhat prepared stage with a score of 4.32 . The changes that will be made should be communicated widely to the employees so that employees can be interested to participate in the change, then will be achieved a successful process of change (Kotter, J., 2011). Some of the errors that occur in communication to make changes are the communication that is performed at the one-time meeting, giving a lecture that is too long by the organization's peak of employees, giving senior leader talks Repeatedly without being offset by the implementation of the given discourse (Kahar, 2009). Some of these things can cause failure to communicate a change to be made. It should be that organisations can inform the strategy of changes to all employees from the bottom level to the top leader, organisations must also explain the advantages and disadvantages of making 
those changes, and the organization also Have to rely on a strong leadership factor in communicating vision through programs that run.

The second indicator that serves as the benchmark readiness to change at Jemursari Islamic Hospital Surabaya is a support or sponsorship. The results showed that most of the respondents were at a ready level with a percentage of $64.77 \%$ related to the sponsorship indicators. Support in this case is a given support from a visionary who will help the team change in the face of resistance. Instructions and support from the organization leader are required when such changes occur.

The third indicator that serves as the benchmark readiness to change in the Jemursari Islamic Hospital is the stakeholders. The results showed that the interested party indicator was at a ready level with a score of 5.06. Stakeholders in management are managing important networks owned by the organization in the management cycle to support a change management process. The changes that will be made require participation in the stakeholders themselves in order to implement changes to the organization itself.

The fourth indicator that is used as the benchmark readiness to change in Jemursari Islamic Hospital is readiness. The results showed that the readiness indicator was at a ready level with a score of 4.85 Readiness in this case it is the readiness of the individual to make changes in the organization. The organization that is ready to make changes is an organization that can make people in it to adapt to the changes that occur and provide the right tools and information in supporting the changes that occur.

The fifth indicator that is used as the benchmark readiness to change in Jemursari Islamic Hospital is training or training. The results showed that the Training indicator was at a ready level with a score of 4.86 . Training is a training that employees need in dealing with a change. Organisations that make changes need to know the new knowledge and skills in order to create a good change.

The results of the data processing related readiness to change of total respondents related to the five indicators indicate that four of the five indicators stated that the respondents of Jemursari Islamic Hospital are ready to do changes from non- Primary education Hospital. Only one indicator has the result of a somewhat prepared change. Indicators that have somewhat prepared results are the communication indicators. The statement on the communication indicators that have the lowest judgment is related to the continuity of the delivery of vision, strategy, and the plan of change into primary education Hospital. This indicates that communication regarding vision, strategy, and plan of change is not carried out repeatedly. There is a possibility that communication related to the vision, strategy, and plan of change is only done occasionally by the top of the organization, so it can cause employees to be somewhat prepared to make changes.

Examined the influence of changing readiness, commitment to organization and communication about organizational changes to the implementation of the performance management system mentioned that communication about Organizational changes have a significant relationship with the Organization's implementation. Some of the causes of this relationship include good communication in the process of change in the organization helping individuals to prepare themselves as well as to form a desolation of changes.

Indicators located at the ready level are indicators related to sponsorship, stakeholders, readiness, and training. The sponsorship indicators at the level are ready to indicate that the changes made from noneducational hospitals to primary education hospital get support from the organization leadership. The organization leadership can provide support to the hospital staff in the form of motivation to make changes. 
Support either in the form of motivation can be given by the leader of the organization in the form of policies that support change or in the form of the activity itself. That way, employees will become motivated because they feel that the organization's leadership is giving attention and concern to the changes. The highest value sponsorship statement is related to the executive leadership or the Director who has the necessary authority over human resources, processes and systems in the authorization and funding of change initiatives. This could indicate that the hospital has a leader that can motivate its employees to make a change, so that the value becomes great.

The indicators at the next ready level are stakeholders. This shows that the leadership from Jemursari Islamic Hospital Surabaya has a strong cooperation with interested parties in making the change, for example, is the hospital leader appoint a Special Committee To handle changes from non-educational hospitals to primary education hospital. Statements on stakeholders who have the highest value in determining readiness for changes from non-educational hospitals to primary education hospital are related to executive leadership or director willing and able to build a coalition for change and able to manage resistance from all stakeholders. With the establishment of a special committee in the handling of changes in Islamic hospital Surabaya, non education becomes primary education RS shows that the hospitals leadership has built a coalition for changes involving interested parties such as special committee that addresses the issue of such change.

The indicator located at the next ready level is readiness. Readiness In this regard is the readiness of the individual to change an organization. The high readiness value shows that the need for human resources and also the need for supporting tools in making changes from noneducational hospitals to primary education hospital has been identified, so the hospital can be said to be ready for the change. The readiness related statement that has the highest value is related to the structured change management approach has been communicated and applied to the change process into the primary education hospital. This indicates that the arrangement of all needs of the hospital changes has been planned and done with the best possible action.

The last indicator that has a level value ready to make changes is training. This training is aimed to achieve the desired performance by an organization's employees. This indicates that the change to become a primary education hospital has been done well in Jemursari Islamic Hospital Surabaya, so that the change process will be easily accepted by the employees. Statements from the training indicators that have the highest value are related hospitals understand and strengthen the competency of skills and knowledge required by the employees to face changes to the primary education hospital. This indicates that the hospital has provided training training that can support and improve the knowledge of each of its employees based on the competencies and expertise owned by each employee. Thus, the change of Jemursari Islamic Hospital becomes main education hospital will be realized well.

\section{CONCLUSION}

Based on the five indicators used to measure readiness to change which are communication indicators, stakeholders, sponsorship, readiness, and training, only communication indicators have a relatively ready level, while the four other indicators have a ready level. The results of the research conducted from all respondents related to readiness to change in Islamic Hospital Jemursari showed that respondents were ready to change from non-educational hospitals to primary education hospital with a percentage of $85.23 \%$. It shows that Jemursari Islamic Hospital is ready to 
change from a non-educational hospital to a primary education RS.

The recommendation given to Jemursari Islamic Hospital Surabaya is to improve the communication that is related to the vision and strategy in making changes from non-educational hospitals to primary education hospital, so that the communication indicator has Level is ready. Thus, Jemursari Islamic Hospital can be transformed into a primary education hospital.

\section{REFERENCE}

Departement of Health, 2009. Pedoman Klasifikasi dan Standar Rumah Sakit Pendidikan.
Information Technology Leadership Academy., 2014. Organizational Change Management Readiness Guide.

Kahar, I., 2009. Konesp Kepemimpinan dalam Perubahan Organisasi (Organizational Change) pada Perpustakaan Perguruan Tinggi. Jurnal Studi Perpustakaan dan Informasi, 4(1).

Kotter, J., 2011. Change Management vs. Change Leadership--What's the Difference? Forbes online, 12(21), p.11.

Weiner, B.J., 2009. A theory of organizational readiness for change. Implementation science, 4(1), p.67. 